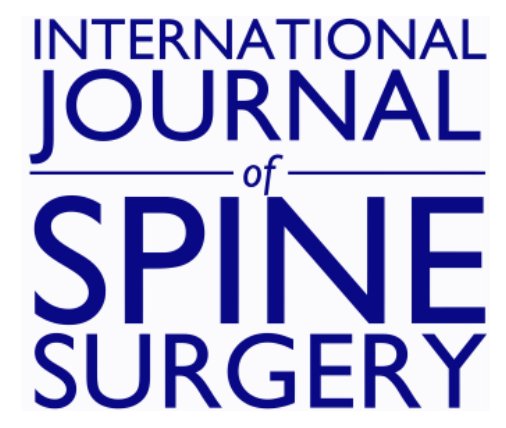

\title{
Most Cited Publications in Cervical Spine Surgery
}

Yu Chao Lee, Francis Brooks, Simon Sandler, Yun-Hom Yau, Michael Selby and Brian Freeman

Int J Spine Surg 2017, 11 (3)

doi: https://doi.org/10.14444/4019

http://ijssurgery.com/content/11/3/19

This information is current as of April 25, 2023.

Email Alerts Receive free email-alerts when new articles cite this article. Sign up at: http://ijssurgery.com/alerts

The International Journal of Shine Surgerht 2397 Waterbury Circle, Suite 1,

Aurora, IL 60504, Phone: +1-630-375-1432

(C) 2017 ISASS. All Rights Reserved. 


\section{Most Cited Publications in Cervical Spine Surgery}

Yu Chao Lee, Francis Brooks, Simon Sandler, Yun-Hom Yau, Michael Selby, Brian Freeman

Royal Adelaide Hospital, Adelaide, Australia

\section{Abstract}

Purpose

The purpose of this study is to perform a citation analysis on the most frequently cited articles in the topic of cervical spine surgery and report on the top 100 most cited publication in this topic.

\section{Methods}

We used the Thomson Reuters Web of Science to search citations of all articles from 1945 to 2015 relevant to cervical spine surgery and ranked them according to the number of citations. The 100 most cited articles that matched the search criteria were further analyzed by number of citations, first author, journal, year of publication, country and institution of origin.

Results

The top 100 cited articles in the topic of cervical spine surgery were published from 1952-2011. The number of citations ranged from 106 times for the 100th paper to 1206 times for the top paper. The decade of 1990-1999 saw the most publications. The Journal of Spine published the most articles, followed by Journal of Bone and Joint Surgery America. Investigators from America authored the most papers and The University of California contributed the most publications. Cervical spine fusion was the most common topic published with 36 papers, followed by surgical technique and trauma.

\section{Conclusion}

This article identifies the 100 most cited articles in cervical spine surgery. It has provided insight to the history and development in cervical spine surgery and many of which have shaped the way we practice today.

CERVICAL SPINE

KEYWORDS: CERVICAL SPINE, SURGERY, CITATION

VOLUME 11 ISSUE 3 DOI: 10.14444/4019

PAGES 145 - 159

\section{Introduction}

Cervical spine surgery owes its advancement to key research which has shaped modern practice. Many papers are published in this area but only a few make a lasting impact to the scientific community.

A citation is recognition of an author's work by their peers and may acknowledge the impact that their work has. Bibliometric analysis has become a popular way of providing an insight into advancements and highlighting key articles in a certain field. Several studies have evaluated the impact that articles have made in their respective field. ${ }^{1-4}$ Citation analysis involves evaluating an article based on the number of citations it receives. The list it generates may identify individuals who have contributed greatly to the scientific community.
The purpose of this study is to identify trends and characteristics which make an article highly cited in the field of cervical spine surgery. We performed a citation analysis on the most frequently cited articles in cervical spine surgery using methods validated in other similar published studies. ${ }^{1-4}$

\section{Methods}

The Institute for Scientific information has collected information on journal citations since 1945. Their current system is known as "Science Citation index" and this database was searched using the Thomson Reuters Web of Science for all articles from 1945 to 2015. The search term was "Cervical Spine" and it was limited to the English language. This search was performed in November 2015. The results were then carefully reviewed by two authors (YL and FB) and 
only those relevant to the cervical spine were selected. The 100 most cited articles that matched the search criteria were further analyzed by number of citations, first author, journal, year of publication, country and institution of origin and level of evidence. The total numbers of citations were compared to the average yearly citation for each article.

\section{Results}

The 100 most cited articles in the topic of cervical spine surgery were published from 1952-2011. These papers, their corresponding authors, and number of citations are shown in Table 1 . The number of citations ranged from 106 times for the 100th paper to 1206 times for the top paper in a total of 15 journals. The decade of 1990-1999 saw the most publications with 36 articles, followed by 2000-2009 with 33 articles (Table 2). The oldest article was by Bailey ${ }^{5}$ published in 1952; and Carragee et al. ${ }^{6}$ published the most recent article in 2011. 
Table 1. Top 100 cited papers in Cervical Spine Surgery.

\begin{tabular}{|c|c|c|c|c|}
\hline Rank & Authors & Title & Citations & $\begin{array}{l}\text { Level of } \\
\text { Evidence }\end{array}$ \\
\hline 1 & $\begin{array}{l}\text { Frankel et } \\
\text { al. }^{7}\end{array}$ & The Value Of Postural Reduction In The Initial Management Of Closed Injuries Of The Spine With Paraplegia And Tetraplegia. I. & 1207 & 3 \\
\hline 2 & $\begin{array}{l}\text { Vernon et } \\
\text { al. }^{9}\end{array}$ & The Neck Disability Index - A Study Of Reliability And Validity & 959 & 2 \\
\hline 3 & $\begin{array}{l}\text { Smith et } \\
\text { al. }\end{array}$ & The Treatment Of Certain Cervical-Spine Disorders By Anterior Removal Of The Intervertebral Disc And Interbody Fusion & 724 & 4 \\
\hline 4 & $\begin{array}{l}\text { Hilibrand et } \\
\text { al. }^{23}\end{array}$ & Radiculopathy And Myelopathy At Segments Adjacent To The Site Of A Previous Anterior Cervical Arthrodesis & 641 & 2 \\
\hline 5 & $\begin{array}{l}\text { Harms et } \\
\text { al. }{ }^{7}\end{array}$ & Posterior C1-C2 Fusion With Polyaxial Screw And Rod Fixation & 624 & 2 \\
\hline 6 & $\begin{array}{l}\text { Hoffman et } \\
\text { al. }{ }^{24}\end{array}$ & Validity Of A Set Of Clinical Criteria To Rule Out Injury To The Cervical Spine In Patients With Blunt Trauma. & 437 & 2 \\
\hline 7 & $\begin{array}{l}\text { Silber et } \\
\text { al. }\end{array}$ & Donor Site Morbidity After Anterior Iliac Crest Bone Harvest For Single-Level Anterior Cervical Discectomy And Fusion & 399 & 2 \\
\hline 8 & $\begin{array}{l}\text { Bohlman et } \\
\text { al. }{ }^{26}\end{array}$ & Robinson Anterior Cervical Diskectomy And Arthrodesis For Cervical Radiculopathy - Long-Term Follow-Up Of 100 And 22 Patients & 396 & 3 \\
\hline 9 & $\begin{array}{l}\text { Carragee et } \\
\text { al. }^{6}\end{array}$ & A Critical Review Of Recombinant Human Bone Morphogenetic Protein-2 Trials In Spinal Surgery: Emerging Safety Concerns And Lessons Learned & 383 & 1 \\
\hline 10 & $\begin{array}{l}\text { Boden et } \\
\text { al. } .^{27}\end{array}$ & Abnormal Magnetic-Resonance Scans Of The Cervical-Spine In Asymptomatic Subjects - A Prospective Investigation & 382 & 3 \\
\hline 11 & Bohlman ${ }^{28}$ & Acute Fractures And Dislocations Of The Cervical-Spine - Analysis Of 300 Hospitalized-Patients And Review Of The Literature & 382 & 2 \\
\hline 12 & Stiell et al. ${ }^{29}$ & The Canadian C-Spine Rule For Radiography In Alert And Stable Trauma Patients & 359 & 2 \\
\hline 13 & $\begin{array}{l}\text { Ranawat et } \\
\text { al. } .^{30}\end{array}$ & Cervical-Spine Fusion In Rheumatoid-Arthritis & 338 & 3 \\
\hline 14 & $\begin{array}{l}\text { Resnick et } \\
\text { al. }^{31}\end{array}$ & Radiographic And Pathologic Features Of Spinal Involvement In Diffuse Idiopathic Skeletal Hyperostosis (Dish) & 338 & 3 \\
\hline 15 & $\begin{array}{l}\text { Bailey et } \\
\text { al. }{ }^{32}\end{array}$ & Stabilization Of The Cervical Spine By Anterior Fusion & 334 & 3 \\
\hline 16 & $\begin{array}{l}\text { Bovim et } \\
\text { al. }{ }^{33}\end{array}$ & Neck Pain In The General-Population & 330 & 2 \\
\hline 17 & $\begin{array}{l}\text { Hirabayashi } \\
\text { et al. }^{34}\end{array}$ & Expansive Open-Door Laminoplasty For Cervical Spinal Stenotic Myelopathy & 323 & 3 \\
\hline 18 & $\begin{array}{l}\text { Payne et } \\
\text { al. }{ }^{35}\end{array}$ & The Cervical Spine - An Anatomico-Pathological Study Of 70 Specimens (Using A Special Technique) With Particular Reference To The Problem Of Cervical Spondylosis & 291 & $\mathrm{~N} / \mathrm{A}$ \\
\hline 19 & $\begin{array}{l}\text { Schneider et } \\
\text { al. }^{36}\end{array}$ & The Syndrome Of Acute Central Cervical Spinal Cord Injury - With Special Reference To The Mechanisms Involved In Hyperextension Injuries Of Cervical Spine & 288 & 4 \\
\hline 20 & $\begin{array}{l}\text { Shields et } \\
\text { al. }{ }^{22}\end{array}$ & Adverse Effects Associated With High-Dose Recombinant Human Bone Morphogenetic Protein-2 Use In Anterior Cervical Spine Fusion & 287 & 2 \\
\hline 21 & Eck et al. ${ }^{37}$ & Biomechanical Study On The Effect Of Cervical Spine Fusion On Adjacent-Level Intradiscal Pressure And Segmental Motion & 286 & $\mathrm{~N} / \mathrm{A}$ \\
\hline 22 & $\begin{array}{l}\text { Barnsley et } \\
\text { al }^{38}\end{array}$ & Whiplash Injury & 286 & 3 \\
\hline 23 & Allen et al. ${ }^{39}$ & A Mechanistic Classification Of Closed, Indirect Fractures And Dislocations Of The Lower Cervical-Spine & 269 & 3 \\
\hline 24 & $\begin{array}{l}\text { Wright et } \\
\text { al. }^{40}\end{array}$ & Vertebral Artery Injury In C1-2 Transarticular Screw Fixation: Results Of A Survey Of The Aans/Cns Section On Disorders Of The Spine And Peripheral Nerves & 266 & 3 \\
\hline 25 & Pang et al. ${ }^{41}$ & Spinal-Cord Injury Without Radiographic Abnormalities In Children & 265 & 3 \\
\hline 26 & $\begin{array}{l}\text { Robinson et } \\
\text { al. }{ }^{13}\end{array}$ & The Results Of Anterior Interbody Fusion Of The Cervical Spine & 262 & 3 \\
\hline 27 & $\begin{array}{l}\text { Schrader et } \\
\text { al. }^{42}\end{array}$ & Natural Evolution Of Late Whiplash Syndrome Outside The Medicolegal Context & 259 & 3 \\
\hline 28 & Sen et $\mathrm{al}^{43}$ & An Extreme Lateral Approach To Intradural Lesions Of The Cervical-Spine And Foramen Magnum & 258 & 3 \\
\hline 29 & Jones et al. ${ }^{44}$ & 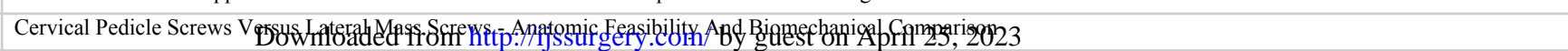 & 247 & 4 \\
\hline
\end{tabular}




\begin{tabular}{|c|c|c|c|c|}
\hline 30 & $\begin{array}{l}\text { Abumi et } \\
\text { al. }{ }^{45}\end{array}$ & Complications Of Pedicle Screw Fixation In Reconstructive Surgery Of The Cervical Spine & 240 & 3 \\
\hline 31 & Gore et $\mathrm{al}^{46}$ & Roentgenographic Findings Of The Cervical-Spine In Asymptomatic People & 237 & 3 \\
\hline 32 & $\begin{array}{l}\text { Panjabi et } \\
\text { al. }^{47}\end{array}$ & Cervical Human Vertebrae - Quantitative 3-Dimensional Anatomy Of The Middle And Lower Regions & 235 & 3 \\
\hline 33 & $\begin{array}{l}\text { Radanov et } \\
\text { al. }^{48}\end{array}$ & Long-Term Outcome After Whiplash Injury - A 2-Year Follow-Up Considering Features Of Injury Mechanism And Somatic, Radiologic, And Psychosocial Findings & 231 & 3 \\
\hline 34 & Grob et al. ${ }^{49}$ & Atlantoaxial Fusion With Transarticular Screw Fixation & 231 & 4 \\
\hline 35 & $\begin{array}{l}\text { Hurwitz et } \\
\text { al. }^{50}\end{array}$ & Manipulation And Mobilization Of The Cervical Spine - A Systematic Review Of The Literature & 230 & 2 \\
\hline 36 & $\begin{array}{l}\text { Kotani et } \\
\text { al. }{ }^{51}\end{array}$ & Biomechanical Analysis Of Cervical Stabilization Systems - An Assessment Of Transpedicular Screw Fixation In The Cervical-Spine & 229 & 3 \\
\hline 37 & Jull et al. ${ }^{52}$ & A Randomized Controlled Trial Of Exercise And Manipulative Therapy For Cervicogenic Headache & 228 & 2 \\
\hline 38 & $\begin{array}{l}\text { Jeanneret et } \\
\text { al. }^{14}\end{array}$ & Primary Posterior Fusion-C1/2 In Odontoid Fractures - Indications, Technique, And Results Of Transarticular Screw Fixation & 227 & 3 \\
\hline 39 & $\begin{array}{l}\text { Sambrook et } \\
\text { al. }^{53}\end{array}$ & Genetic Influences On Cervical And Lumbar Disc Degeneration - A Magnetic Resonance Imaging Study In Twins & 215 & 3 \\
\hline 40 & Penning ${ }^{54}$ & Normal Movements Of Cervical-Spine & 214 & 4 \\
\hline 41 & $\begin{array}{l}\text { Ylinen et } \\
\text { al. }{ }^{55}\end{array}$ & Active Neck Muscle Training In The Treatment Of Chronic Neck Pain In Women - A Randomized Controlled Trial & 213 & 2 \\
\hline 42 & Davis et al. ${ }^{56}$ & The Etiology Of Missed Cervical-Spine Injuries & 213 & 3 \\
\hline 43 & $\begin{array}{l}\text { Mummaneni } \\
\text { et al. }{ }^{7}\end{array}$ & Clinical And Radiographic Analysis Of Cervical Disc Arthroplasty Compared With Allograft Fusion: A Randomized Controlled Clinical Trial & 212 & 2 \\
\hline 44 & Fang et al..$^{58}$ & Direct Anterior Approach To The Upper Cervical Spine & 212 & 4 \\
\hline 45 & $\begin{array}{l}\text { Goffin et } \\
\text { al. } .^{59}\end{array}$ & Intermediate Follow-Up After Treatment Of Degenerative Disc Disease With The Bryan Cervical Disc Prosthesis: Single-Level And Bi-Level & 211 & 3 \\
\hline 46 & $\begin{array}{l}\text { Teresi et } \\
\text { al. }^{.0}\end{array}$ & Asymptomatic Degenerative Disk Disease And Spondylosis Of The Cervical-Spine - Mr Imaging & 210 & 3 \\
\hline 47 & $\begin{array}{l}\text { Abumi et } \\
\text { al. }{ }^{61}\end{array}$ & Transpedicular Screw Fixation For Traumatic Lesions Of The Middle And Lower Cervical-Spine - Description Of The Techniques And Preliminary-Report & 209 & 4 \\
\hline 48 & $\begin{array}{l}\text { Conlon et } \\
\text { al. }^{62}\end{array}$ & Rheumatoid Arthritis Of Cervical Spine - An Analysis Of 333 Cases & 209 & 3 \\
\hline 49 & Rogers $^{63}$ & Fractures And Dislocations Of The Cervical Spine - An End-Result Study & 209 & 3 \\
\hline 50 & $\begin{array}{l}\text { Emery et } \\
\text { al. }{ }^{64}\end{array}$ & Anterior Cervical Decompression And Arthrodesis For The Treatment Of Cervical Spondylotic Myelopathy - Two To Seventeen-Year Follow-Up & 202 & 3 \\
\hline 51 & $\begin{array}{l}\text { Vaccaro et } \\
\text { al. }{ }^{65}\end{array}$ & Early Failure Of Long Segment Anterior Cervical Plate Fixation & 198 & 3 \\
\hline 52 & $\begin{array}{l}\text { Youdas et } \\
\text { al. }\end{array}$ & Reliability Of Measurements Of Cervical-Spine Range Of Motion - Comparison Of 3 Methods & 198 & 3 \\
\hline 53 & $\begin{array}{l}\text { Southwick } \\
\text { et al. }{ }^{67}\end{array}$ & Surgical Approaches To The Vertebral Bodies In The Cervical And Lumbar Regions & 198 & 4 \\
\hline 54 & $\begin{array}{l}\text { Buskila et } \\
\text { al. } .^{8}\end{array}$ & Increased Rates Of Fibromyalgia Following Cervical Spine Injury - A Controlled Study Of 161 Cases Of Traumatic Injury & 195 & 3 \\
\hline 55 & $\begin{array}{l}\text { Goffin et } \\
\text { al. }^{69}\end{array}$ & Long-Term Follow-Up After Interbody Fusion Of The Cervical Spine & 193 & 3 \\
\hline 56 & Stiell et al. ${ }^{70}$ & The Canadian C-Spine Rule Versus The Nexus Low-Risk Criteria In Patients With Trauma & 193 & 3 \\
\hline 57 & $\begin{array}{l}\text { Goffin et } \\
\text { al. }^{18}\end{array}$ & Preliminary Clinical Experience With The Bryan Cervical Disc Prosthesis & 193 & 3 \\
\hline 58 & $\begin{array}{l}\text { Flanders et } \\
\text { al. }^{71}\end{array}$ & Acute Cervical-Spine Trauma - Correlation Of Mr Imaging Findings With Degree Of Neurologic Deficit & 193 & 2 \\
\hline 59 & $\begin{array}{l}\text { Sawin et } \\
\text { al. }^{72}\end{array}$ & A Comparative Analysis Of Fusion Rates And Donor-Site Morbidity For Autogeneic Rib And Iliac Crest Bone Grafts In Posterior Cervical Fusions & 192 & 3 \\
\hline 60 & Clark et al. ${ }^{73}$ & $\begin{array}{l}\text { Fractures Of The Dens - A Multicenter Study } \\
\text { Downloaded from http } / / \text { iissurgery com/ by guest on April } 25.2023\end{array}$ & 192 & 2 \\
\hline
\end{tabular}




\begin{tabular}{|c|c|c|c|c|}
\hline 61 & $\begin{array}{l}\text { Cattell et } \\
\text { al. } .^{44}\end{array}$ & Pseudosubluxation And Other Normal Variations In Cervical Spine In Children . A Study Of 160 Children & 191 & 3 \\
\hline 62 & $\begin{array}{l}\text { Fountas et } \\
\text { al. }^{75}\end{array}$ & Anterior Cervical Discectomy And Fusion Associated Complications & 190 & 3 \\
\hline 63 & $\begin{array}{l}\text { Kaiser et } \\
\text { al. }{ }^{6}\end{array}$ & Anterior Cervical Plating Enhances Arthrodesis After Discectomy And Fusion With Cortical Allograft & 189 & 3 \\
\hline 64 & $\begin{array}{l}\text { Levine et } \\
\text { al. }^{77}\end{array}$ & The Management Of Traumatic Spondylolisthesis Of The Axis & 189 & 3 \\
\hline 65 & Wada et al. $^{78}$ & Subtotal Corpectomy Versus Laminoplasty For Multilevel Cervical Spondylotic Myelopathy - A Long-Term Follow-Up Study Over 10 Years & 184 & 2 \\
\hline 66 & An et al. $^{21}$ & Comparison Between Allograft Plus Demineralized Bone-Matrix Versus Autograft In Anterior Cervical Fusion - A Prospective Multicenter Study & 184 & 2 \\
\hline 67 & $\begin{array}{l}\text { Smucker et } \\
\text { al. }{ }^{79}\end{array}$ & Increased Swelling Complications Associated With Off-Label Usage Of Rhbmp-2 In The Anterior Cervical Spine & 183 & 4 \\
\hline 68 & $\begin{array}{l}\text { Boden et } \\
\text { al. } .^{80}\end{array}$ & Rheumatoid-Arthritis Of The Cervical-Spine - A Long-Term Analysis With Predictors Of Paralysis And Recovery & 182 & 3 \\
\hline 69 & $\begin{array}{l}\text { Murrey et } \\
\text { al. }^{81}\end{array}$ & $\begin{array}{l}\text { Results Of The Prospective, Randomized, Controlled Multicenter Food And Drug Administration Investigational, Device Exemption Study Of The Prodisc-C Total Disc Replacement Versus Anterior } \\
\text { Discectomy And Fusion For The Treatment Of 1-Level Symmptomatic Cervical Disc Disease }\end{array}$ & 181 & 2 \\
\hline 70 & $\begin{array}{l}\text { Hosono et } \\
\text { al. }^{82}\end{array}$ & Neck And Shoulder Pain After Laminoplasty - A Noticeable Complication & 181 & 3 \\
\hline 71 & $\begin{array}{l}\text { Bazaz et } \\
\text { al. }^{83}\end{array}$ & Incidence Of Dysphagia After Anterior Cervical Spine Surgery - A Prospective Study & 180 & 3 \\
\hline 72 & $\begin{array}{l}\text { Vasavada et } \\
\text { al. }^{84}\end{array}$ & Influence Of Muscle Morphometry And Moment Arms On The Moment-Generating Capacity Of Human Neck Muscles & 179 & $\mathrm{~N} / \mathrm{A}$ \\
\hline 73 & $\begin{array}{l}\text { Dickman et } \\
\text { al. }^{85}\end{array}$ & The Interspinal Method Of Posterior Atlantoaxial Arthrodesis & 178 & 4 \\
\hline 74 & $\begin{array}{l}\text { Panjabi et } \\
\text { al. }^{86}\end{array}$ & Mechanical Properties Of The Human Cervical Spine As Shown By Three-Dimensional Load-Displacement Curves & 176 & N/A \\
\hline 75 & Aker et al. ${ }^{87}$ & Conservative Management Of Mechanical Neck Pain: Systematic Overview And Meta-Analysis & 175 & 1 \\
\hline 76 & $\begin{array}{l}\text { Bishop et } \\
\text { al. }^{20}\end{array}$ & Anterior Cervical Interbody Fusion Using Autogeneic And Allogeneic Bone Graft Substrate: A Prospective Comparative Analysis & 175 & 2 \\
\hline 77 & Itoh et al. ${ }^{88}$ & Technical Improvements And Results Of Laminoplasty For Compressive Myelopathy In The Cervical-Spine & 175 & 3 \\
\hline 78 & $\begin{array}{l}\text { Pellicci et } \\
\text { al. }^{89}\end{array}$ & A Prospective-Study Of The Progression Of Rheumatoid-Arthritis Of The Cervical-Spine & 173 & 2 \\
\hline 79 & $\begin{array}{l}\text { Abumi et } \\
\text { al. }^{90}\end{array}$ & Posterior Occipitocervical Reconstruction Using Cervical Pedicle Screws And Plate-Rod Systems & 172 & 3 \\
\hline 80 & $\begin{array}{l}\text { Heller et } \\
\text { al. }^{11}\end{array}$ & Comparison Of Bryan Cervical Disc Arthroplasty With Anterior Cervical Decompression And Fusion Clinical And Radiographic Results Of A Randomized, Controlled, Clinical Trial & 171 & 2 \\
\hline 81 & $\begin{array}{l}\text { Abumi et } \\
\text { al. }{ }^{92}\end{array}$ & Pedicle Screw Fixation For Nontraumatic Lesions Of The Cervical Spine & 171 & 3 \\
\hline 82 & $\begin{array}{l}\text { Melcher et } \\
\text { al. }{ }^{3}\end{array}$ & Biomechanical Testing Of Posterior Atlantoaxial Fixation Techniques & 170 & N/A \\
\hline 83 & $\begin{array}{l}\text { Katsuura et } \\
\text { al. }{ }^{4}\end{array}$ & Kyphotic Malalignment After Anterior Cervical Fusion Is One Of The Factors Promoting The Degenerative Process In Adjacent Intervertebral Levels & 170 & 3 \\
\hline 84 & Perry et al. ${ }^{95}$ & Total Cervical-Spine Fusion For Neck Paralysis & 170 & 3 \\
\hline 85 & $\begin{array}{l}\text { Matsumoto } \\
\text { et al. }{ }^{66}\end{array}$ & Mri Of Cervical Intervertebral Discs In Asymptomatic Subjects & 169 & 3 \\
\hline 86 & $\begin{array}{l}\text { Johnson et } \\
\text { al. }{ }^{97}\end{array}$ & Cervical Orthoses - Study Comparing Their Effectiveness In Restricting Cervical Motion In Normal Subjects & 167 & N/A \\
\hline 87 & $\begin{array}{l}\text { Richter et } \\
\text { al. }^{98}\end{array}$ & Posterior Atlantoaxial Fixation - Biomechanical In Vitro Comparison Of Six Different Techniques & 166 & N/A \\
\hline 88 & $\begin{array}{l}\text { Bogduk et } \\
\text { al. }{ }^{9}\end{array}$ & Biomechanics Of The Cervical Spine. I: Normal Kinematics & 166 & N/A \\
\hline 89 & Gore et al. ${ }^{100}$ & Neck Pain - A Long-Term Follow-Up Of 205 Patients & 166 & 3 \\
\hline 90 & Torg et al. ${ }^{101}$ & Neurapraxia Of The Cervical Spinal-Cord With Transient Quadriplegia & 166 & 3 \\
\hline
\end{tabular}

Downloaded from http://ijssurgery.com/ by guest on April 25, 2023 


\begin{tabular}{|c|c|c|c|c|}
\hline 91 & $\begin{array}{l}\text { Sakaura et } \\
\text { al. }{ }^{102}\end{array}$ & C5 Palsy After Decompression Surgery For Cervical Myelopathy - Review Of The Literature & 165 & 3 \\
\hline 92 & $\begin{array}{l}\text { Wang et } \\
\text { al. }{ }^{103}\end{array}$ & Increased Fusion Rates With Cervical Plating For Two-Level Anterior Cervical Discectomy And Fusion & 165 & 3 \\
\hline 93 & $\begin{array}{l}\text { Matsunaga } \\
\text { et al. }{ }^{104}\end{array}$ & Strain On Intervertebral Discs After Anterior Cervical Decompression And Fusion & 165 & N/A \\
\hline 94 & $\begin{array}{l}\text { Wainner et } \\
\text { al. }{ }^{105}\end{array}$ & Reliability And Diagnostic Accuracy Of The Clinical Examination And Patient Self-Report Measures For Cervical Radiculopathy & 163 & 3 \\
\hline 95 & Coe et al. ${ }^{106}$ & Biomechanical Evaluation Of Cervical Spinal Stabilization Methods In A Human Cadaveric Model & 162 & N/A \\
\hline 96 & Tan et al. ${ }^{107}$ & Morphometric Evaluation Of Screw Fixation In Atlas Via Posterior Arch And Lateral Mass & 161 & N/A \\
\hline 97 & $\begin{array}{l}\text { Resnick et } \\
\text { al. }{ }^{108}\end{array}$ & Anatomic Suitability Of The C1-C2 Complex For Pedicle Screw Fixation & 161 & 4 \\
\hline 98 & Bailey $^{5}$ & The Normal Cervical Spine In Infants And Children & 161 & 3 \\
\hline 99 & $\begin{array}{l}\text { Resnick et } \\
\text { al. }\end{array}$ & C1-C2 Pedicle Screw Fixation With Rigid Cantilever Beam Construct: Case Report And Technical Note & 160 & 4 \\
\hline 100 & $\begin{array}{l}\text { Hacker et } \\
\text { al. }{ }^{.10}\end{array}$ & A Prospective Randomized Multicenter Clinical Evaluation Of An Anterior Cervical Fusion Cage & 160 & 2 \\
\hline
\end{tabular}


The Spine Journal published the most articles (48 articles), followed by the Journal of Bone and Joint Surgery, America. The top two journals published $57 \%$ of all articles (Table 3 ). Investigators from America authored 52 of the 100 articles, followed by authors from Japan with 13 articles and Germany with 7 articles (Table 4). The institution that contributed the most was the University of California with 9 publications in the top 100 (Table 5). A total of 9 authors contributed $\geq 3$ publications with Abumi, $\mathrm{K}$ and Bohlmann $\mathrm{H}$, having 5 publications in the top 100 (Table 6).

Cervical spine fusion was the most common topic published with 36 articles, followed by articles on surgical technique and trauma (Table 7). When the level of evidence is reviewed, we found that the most

Table 2. Publication dates.

\begin{tabular}{|l|r|}
\hline Decade of publication & Number of Articles \\
\hline Pre-1970 & 13 \\
\hline $1970-1979$ & 5 \\
\hline $1980-1989$ & 12 \\
\hline $1990-1999$ & 36 \\
\hline $2000-2009$ & 33 \\
\hline After 2010 & 1 \\
\hline
\end{tabular}

Table 3. Top Journals of Publication.

\begin{tabular}{|l|r|r|}
\hline Journal & $\begin{array}{r}\text { Impact fac- } \\
\text { tor }\end{array}$ & $\begin{array}{r}\text { Number of arti- } \\
\text { cles }\end{array}$ \\
\hline Spine & 3.024 & 37 \\
\hline $\begin{array}{l}\text { Journal of Bone and Joint Surgery (Ameri- } \\
\text { ca) }\end{array}$ & 5.28 & 20 \\
\hline Journal of Neurosurgery & 3.737 & 6 \\
\hline Radiology & 6.867 & 4 \\
\hline
\end{tabular}

Table 4. Country of Origin for Top articles.

\begin{tabular}{|l|r|}
\hline Country of Origin & Number of Articles \\
\hline USA & 52 \\
\hline Japan & 13 \\
\hline Germany & 7 \\
\hline Canada & 5 \\
\hline Australia & 4 \\
\hline
\end{tabular}

common level of evidence was 3 with only two articles being level 1 (Figure 1). We found that only 24 articles were rated as level 1 or 2 with the remainder being rated as 3 and 4 (Table 1).

Comparison was made between the total number of citations with the average number of citations per year. There was a variation in the ranking with 7 articles ranked in the top 10 by total number of citations and also ranked in the top 10 when ranked by average

Table 5. Top institutions of origin of articles.

\begin{tabular}{|l|r|}
\hline Institution & Number of Articles \\
\hline University of California Group & 9 \\
\hline Emory University & 6 \\
\hline Case Western Reserve University & 5 \\
\hline Hokkaido University & 5 \\
\hline
\end{tabular}

Table 6. Top authors.

\begin{tabular}{|l|r|}
\hline Author & Number of authorship \\
\hline Abumi, K & 5 \\
\hline Bohlmann, H H & 5 \\
\hline Kaneda, K & 4 \\
\hline
\end{tabular}

Table 7. Most popular topic ranked by number of papers.

\begin{tabular}{|l|r|}
\hline Topic & No. of papers \\
\hline Fusion & 36 \\
\hline Surgical Technique & 19 \\
\hline Trauma & 17 \\
\hline Complications & 16 \\
\hline Grafting & 13 \\
\hline
\end{tabular}

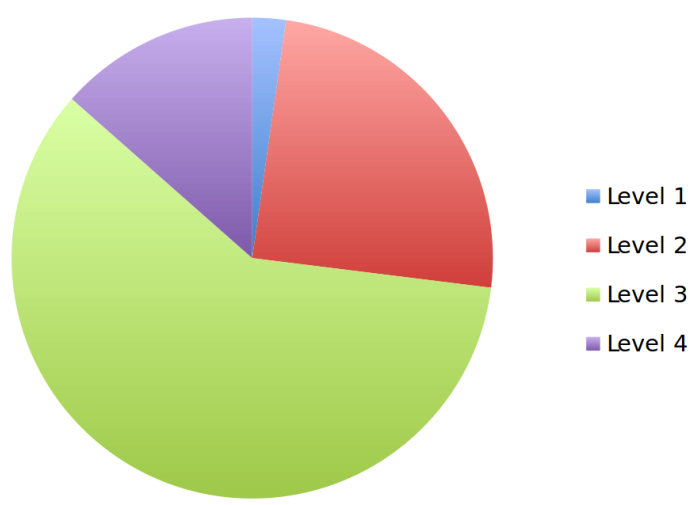

Fig. 1. Level of Evidence. 
(Table 8).

\section{Discussion}

This study identifies the most cited papers on the cervical spine. It provides the features which make an article likely to be highly cited and highlights the journals which may allow work to be cited.

The top most cited paper with 1206 citations is the work by Frankel et al. ${ }^{7}$ on postural reduction in the management of closed injuries of the spine with paraplegia or tetraplegia. While such treatment method is less common, their work on classifying neurological impairment became the basis of the spinal assessment in spinal cord injury patients as part of the American Spinal Injury Association (ASIA) neurological impairment scale. ${ }^{8}$ In their initial description, complete and incomplete spinal cord injuries were subdivided into five categories, without detailing assessment of motor or sensory function. ${ }^{7}$ This was subsequently modified by the ASIA with the addition of key muscle function, key sensory points and presence of sacral sparing added as part of assessment to clarify zones of partial preservation. ${ }^{8}$ This allows greater precision and consistency in defining the extent of spinal cord injury amongst clinicians and researchers.

The second most cited paper is the work by Vernon and Moir, ${ }^{9}$ describing the neck disability index
(NDI), which became the first instrument designed to assess self-rated disability in patients with neck pain. Vernon modelled the NDI on the Oswestry Low Back Pain Disability Questionnaire with the permission of the authors. ${ }^{10}$ Since 1991, the NDI has become the most widely used questionnaire for neck pain, with 959 citations, translation into over 20 languages, and a widely used outcome measure in clinical studies. ${ }^{11}$ The NDI has been useful for prognostication of outcome following whiplash injury, with several studies reporting a low initial NDI predicting recovery and a high score predicting chronicity. ${ }^{11} \mathrm{In}$ addition, high NDI score (>15/50) at 3-36 months following injury strongly correlates with physiological dysfunction such as muscular dysfunction and central sensitization. ${ }^{11}$

The third most cited paper is by Smith and Robinson, ${ }^{12}$ who first describe the anterior approach to the cervical spine in the treatment of symptomatic cervical spondylosis. The authors suggested that disc degeneration, osteophyte formation and foraminal stenosis resulted in brachalgia. In their series of 14 patients who underwent anterior approach and interbody fusion with autologous iliac crest graft they reported symptomatic improvement. ${ }^{12}$ In their subsequent article on 55 patients with longer follow-up, which is also one of the top articles, Robinson continued to report good success with the anterior interbody fusion of cervical spine with low complication rates. ${ }^{13}$ This technique has since become the

Table 8. Comparison of rank by number of citations per year and total citations.

\begin{tabular}{|c|c|c|c|c|}
\hline Authors & Title & $\begin{array}{l}\text { Average } \\
\text { per } \\
\text { Year }\end{array}$ & $\begin{array}{l}\text { Rank } \\
\text { by } \\
\text { average }\end{array}$ & $\begin{array}{l}\text { Rank } \\
\text { by } \\
\text { Total }\end{array}$ \\
\hline $\begin{array}{l}\text { Carragee } \\
\text { et al. }\end{array}$ & $\begin{array}{l}\text { A critical review of recombinant human bone morphogenetic protein-2 trials in spinal surgery: emerging safety concerns and } \\
\text { lessons learned }\end{array}$ & 76.6 & 1 & 9 \\
\hline $\begin{array}{l}\text { Harms et } \\
\text { al. }{ }^{17}\end{array}$ & Posterior C1-C2 fusion with polyaxial screw and rod fixation & 41.6 & 2 & 5 \\
\hline $\begin{array}{l}\text { Vernon } \\
\text { et al. }{ }^{9}\end{array}$ & The neck disability index - A study of reliability and validity & 38.36 & 3 & 2 \\
\hline $\begin{array}{l}\text { Hilibrand } \\
\text { et al. }\end{array}$ & Radiculopathy and myelopathy at segments adjacent to the site of a previous anterior cervical arthrodesis & 37.71 & 4 & 4 \\
\hline $\begin{array}{l}\text { Silber et } \\
\text { al. }^{25}\end{array}$ & Donor site morbidity after anterior iliac crest bone harvest for single-level anterior cervical discectomy and fusion & 30.69 & 5 & 7 \\
\hline $\begin{array}{l}\text { Shields } \\
\text { et al.2. }\end{array}$ & Adverse effects associated with high-dose recombinant human bone morphogenetic protein- 2 use in anterior cervical spine fusion & 28.7 & 6 & 20 \\
\hline $\begin{array}{l}\text { Hoffman } \\
\text { et al. }{ }^{24}\end{array}$ & Validity of a set of clinical criteria to rule out injury to the cervical spine in patients with blunt trauma. & 27.31 & 7 & 6 \\
\hline $\begin{array}{l}\text { Murrey } \\
\text { et al. }{ }^{81}\end{array}$ & $\begin{array}{l}\text { Results of the prospective, randomized, controlled multicenter Food and Drug Administration investigational, device exemption } \\
\text { study of the ProDisc-C total disc replacement versus anterior discectomy and fusion for the treatment of 1-level symptomatic } \\
\text { cervical disc disease }\end{array}$ & 25.86 & 8 & 69 \\
\hline $\begin{array}{l}\text { Frankel } \\
\text { et al. }\end{array}$ & The value of postural reduction in the initial management of closed injuries of the spine with paraplegia and tetraplegia. I. & 25.68 & 9 & 1 \\
\hline $\begin{array}{l}\text { Heller et } \\
\text { al. }{ }^{91}\end{array}$ & $\begin{array}{l}\text { Comparison of BRYAN Cervical Disc Arthroplasty With Anterior Cervical Decompression and Fusion Clinical and Radiographic } \\
\text { Results of a Randomized, Controlled, Clinical Trial }\end{array}$ & 24.43 & 10 & 80 \\
\hline
\end{tabular}

Downloaded from http://ijssurgery.com/ by guest on April 25, 2023 
gold standard for the treatment of cervical spondylosis and cervical myelopathy.

In contrast to previous studies where 1980s was the most prolific decade for articles, ${ }^{3}$ the decades of 1990s saw the most publications in cervical spine surgery. This is similar to papers published in Foot and ankle surgery, ${ }^{4}$ sports medicine, ${ }^{111}$ shoulder surgery ${ }^{112}$ and spine surgery. ${ }^{113}$ These two decades coincided with the development of improved instrumentation and surgical technique for managing cervical instability and reflect the relatively young field of spinal surgery. In 1992, Jeanneret and Magerl ${ }^{14}$ (ranked 38) described the trans-articular atlantoaxial screw fixation technique for treating unstable odontoid fractures, which was alternate to the then more popular Gallie ${ }^{15}$ or Brooks ${ }^{16}$ type posterior fusion technique which lacked primary stability for treatment of unstable C2 peg fractures. In 2001, Harms and Melcher 17 (ranked 5) described another technique for treating the atlantoaxial joint instability with posterior atlas and axis screw-rod fixation and fusion. Both the Magerl and Harms methods remained popular techniques to date, demonstrating high fusion rate for treating $\mathrm{C} 2$ fractures. The decade of 2000-2009 saw an improvement in cervical disc arthroplasty design and increasing use for treating cervical myelopathy or radiculopathy. Goffin et al. ${ }^{18}$ in 2002 (ranked 45) described their preliminary experience with the Bryan Disc Replacement, reporting on the safety of the device and favorable results at short term follow-up. Proponents of cervical disc arthroplasty argue that maintenance of motion avoids adjacent segment degeneration. More than 15 designs of cervical disc arthroplasty are undergoing ongoing clinical trails to determine its efficacy. ${ }^{19}$

Cervical fusion was the most popular topic with 36 papers featured in the 100 articles we reviewed. Anterior fusion was the most commonly described technique and is currently the gold standard for treating mid to lower cervical spine disorder ranging from fracture-dislocation, instability and degenerative disc disease. Popularized by Smith and Robinson, ${ }^{12}$ the technique saw a trend to improve fusion rates through grafting which is the $5^{\text {th }}$ most common topic. Bishop et al. ${ }^{20}$ (ranked 76) use of allograft and An et al. ${ }^{21}$ (ranked 66) used allograft plus demineral- ized bone matrix for anterior cervical fusion but found this not to be superior, with high rates of pseudoarthrosis and graft collapse. More recent interest has been the use of BMP and it's association with higher complication rates. Interestingly complications as a subject ranked $4^{\text {th }}$ in this study. Published in 2006 and ranked 20, Shields et al. ${ }^{22}$ reported the adverse effects associated with high-dose recombinant human bone morphogenetic protein-2 use in anterior cervical spine fusion. This was one of the first studies that reported on the adverse events associated with rhBMP-2 in cervical spine surgery, including life threatening events such as delayed haematoma, soft tissue swelling and airway compromise. This is contrary to initial industry sponsored rhBMP- 2 on its use reporting a $0 \%$ adverse event rate. $^{6}$

Classification systems and outcome tools have been found in other citation analysis to be prominent features. The top two articles in this analysis are describing classification systems and outcome tools respectively. This shows the importance to have a well validated outcome tool in clinical research as it allows the effect of a treatment to be assessed between studies and allows direct comparison of one technique with another.

The most popular journal for publication was the Spine Journal. This highlights its role as a journal for both neurosurgical and orthopaedic spinal surgeons to read. Nearly two thirds of the 100 most cited articles were published in just two journals. The journal of Bone and Joint Surgery, America was the second most popular destination for research. These two journals both have high impact and highlight the need to publish work in a high impact journal.

The United States was the country with the most number of articles included in the 100 articles we reviewed. This is similar to results from many previous bibliometric anaylsis papers. ${ }^{3,4111,112,113}$ Japan featured as the second most prolific nation and this relates to their role in the development and advancement of the laminoplasty technique for the management of cervical cord compression.

All the papers which included randomized trials 
were published since the year 2000, highlighting an improvement in the quality of research being performed. The papers which were of lower level of evidence all tended to be published earlier. This shows that the quality of research being performed has improved as better understanding of clinical research is developed. The most common level of evidence were 3 and 4 which are similar to other orthopedic bibliometric analysis papers. ${ }^{11,112,113}$ This highlights the difficulty that we have in surgical specialties in performing good randomized control trials.

A similar bibliometric analysis has been published on the cervical spine by Ruegsegger et al. ${ }^{114}$ They performed a bibliometric analysis using the same database but a different key word search. This we believe is why our independent study results differ to theirs. Their method, we feel, will have resulted in the exclusion of some key articles we included.

Previous papers on bibliometric analysis have restricted their analysis to the journals with higher impact factor. We did not restrict our search by this, as it may create a list which excludes key articles. As a result, we feel our citation analysis is more powerful. Some question the use of citation analysis as a scientific tool. We feel these lists are beneficial for junior clinicians and researchers alike as it highlights key features of research and provides a historic account of the developments. Whilst some articles will be highly cited due to their controversial nature however we feel that these are likely to be few compared with those that advance the specialty. Previous papers have highlighted the unfair advantage that ranking by total citations can give an article which has been published for a long time. This can be seen in our comparison of articles by number of citations per year. Carragee et al. ${ }^{6}$ article has an average citation of 76.6 per year compared with Frankel et al., ${ }^{7,25,68}$. We see articles on cervical disc arthroplasty advancing significantly when we rank by average per year. This highlight that these papers are important now and are likely to feature in bibliometric analysis in the future.

\section{Conclusion}

This article shows the journals which are likely to provide an author with high levels of readership and potentially high citation. It provides an insight to the development of modern cervical spine surgery. With continued development of surgical implant technology and research methods the features of this list will change to reflect these newer techniques and approaches. This article provides a current insight into the most cited cervical spine papers.

\section{Reference}

1. Steinberger J, Skovrlj B, Caridi JM, Cho SK. The top 100 classic papers in lumbar spine surgery. Spine (Phila Pa 1976). 2015;40:10.740-7.

2. O'Neill SC, Butler JS, McGoldrick N, O'Leary $\mathrm{R}$, Synnott K. The 100 most cited papers in spinal deformity surgery: a bibliometric analysis. Orthop Rev (Pavia). 2014;6:4.5584.

3. Kelly JC, Glynn RW, O'Briain DE, Felle P, McCabe JP. The 100 classic papers of orthopaedic surgery: a bibliometric analysis. J Bone Joint Surg Br. 2010;92:10.1338-43.

4. Bayley M, Brooks F, Tong A, Hariharan K. The 100 most cited papers in foot and ankle surgery. Foot (Edinb). 2014;24:1.11-6.

5. Bailey DK. THE NORMAL CERVICAL SPINE IN INFANTS AND CHILDREN. Radiology. 1952;59:5.712-9.

6. Carragee EJ, Hurwitz EL, Weiner BK. A critical review of recombinant human bone morphogenetic protein-2 trials in spinal surgery: emerging safety concerns and lessons learned. Spine Journal. 2011;11:6.471-91.

7. Frankel HL, Hancock DO, Hyslop G, Melzak J, Michaelis LS, Ungar GH, et al. The value of postural reduction in the initial management of closed injuries of the spine with paraplegia and tetraplegia. I. Paraplegia. 1969;7:3.179-92.

8. Kirshblum SC, Biering-Sorensen F, Betz R, Burns $S$, Donovan W, Graves DE, et al. International standards for neurological classification of spinal cord injury: cases with classification challenges. Top Spinal Cord Inj Rehabil. 2014;20:2.81-9.

9. Vernon H, Mior S. THE NECK DISABILITY INDEX - A STUDY OF RELIABILITY AND VALIDITY. J Manip Physiol Ther. 1991;14:7.409-15. 10. Fairbank JC, Couper J, Davies JB, O'Brien JP.

Downloaded from http://ijssurgery.com/ by guest on April 25, 2023 
The Oswestry low back pain disability questionnaire. Physiotherapy. 1980;66:8.271-3.

11. Vernon H. The Neck Disability Index: state-ofthe-art, 1991-2008. J Manipulative Physiol Ther. 2008;31:7.491-502.

12. Smith GW, Robinson RA. THE TREATMENT OF CERTAIN CERVICAL-SPINE DISORDERS BY ANTERIOR REMOVAL OF THE INTERVERTEBRAL DISC AND INTERBODY FUSION. $J$ Bone Joint Surg-Am Vol. 1958;40:3.607-24.

13. Robinson RA, Walker AE, Ferlic DC, Wiecking DK. THE RESULTS OF ANTERIOR INTERBODY FUSION OF THE CERVICAL SPINE. $J$ Bone Joint Surg-Am Vol. 1962;44:8.1569-87.

14. Jeanneret B, Magerl F. PRIMARY POSTERIOR FUSION-C1/2 IN ODONTOID FRACTURES INDICATIONS, TECHNIQUE, AND RESULTS OF TRANSARTICULAR SCREW FIXATION. $J$ Spinal Disord. 1992;5:4.464-75.

15. WE G. Fractures and dislocations of the cervical spine. Am J Surg. 1939;46.495-9.

16. Brooks AL, Jenkins EB. Atlanto-axial arthrodesis by the wedge compression method. J Bone Joint Surg Am. 1978;60:3.279-84.

17. Harms J, Melcher RP. Posterior C1-C2 fusion with polyaxial screw and rod fixation. Spine.

2001;26:22.2467-71.

18. Goffin J, Casey A, Kehr P, Liebig K, Lind B, Logroscino C, et al. Preliminary clinical experience with the Bryan Cervical Disc Prosthesis. Neurosurgery. 2002;51:3.840-5.

19. Orr RD, Postak PD, Rosca M, Greenwald AS. The current state of cervical and lumbar spinal disc arthroplasty. J Bone Joint Surg Am. 2007;89 Suppl 3.70-5.

20. Bishop RC, Moore KA, Hadley MN. Anterior cervical interbody fusion using autogeneic and allogeneic bone graft substrate: A prospective comparative analysis. J Neurosurg. 1996;85:2.206-10.

21. An HS, Simpson JM, Glover JM, Stephany J. COMPARISON BETWEEN ALLOGRAFT PLUS DEMINERALIZED BONE-MATRIX VERSUS AUTOGRAFT IN ANTERIOR CERVICAL FUSION - A PROSPECTIVE MULTICENTER STUDY. Spine. 1995;20:20.2211-6.

22. Shields LBE, Raque GH, Glassman SD, Campbell M, Vitaz T, Harpring J, et al. Adverse effects as- sociated with high-dose recombinant human bone morphogenetic protein-2 use in anterior cervical spine fusion. Spine. 2006;31:5.542-7.

23. Hilibrand AS, Carlson GD, Palumbo MA, Jones $\mathrm{PK}$, Bohlman HH. Radiculopathy and myelopathy at segments adjacent to the site of a previous anterior cervical arthrodesis. J Bone Joint Surg-Am Vol. 1999;81A:4.519-28.

24. Hoffman JR, Mower WR, Wolfson AB, Todd KH, Zucker MI, Natl Emergency XRUSG. Validity of a set of clinical criteria to rule out injury to the cervical spine in patients with blunt trauma. $N E n g l J$ Med. 2000;343:2.94-9.

25. Silber JS, Anderson DG, Daffner SD, Brislin BT, Leland JM, Hilibrand AS, et al. Donor site morbidity after anterior iliac crest bone harvest for single-level anterior cervical discectomy and fusion. Spine. 2003;28:2.134-9.

26. Bohlman HH, Emery SE, Goodfellow DB, Jones PK. ROBINSON ANTERIOR CERVICAL DISKECTOMY AND ARTHRODESIS FOR CERVICAL RADICULOPATHY - LONG-TERM FOLLOW-UP OF 100 AND 22 PATIENTS. J Bone Joint Surg-Am Vol. 1993;75A:9.1298-307.

27. Boden SD, McCowin PR, Davis DO, Dina TS, Mark AS, Wiesel S. ABNORMAL MAGNETICRESONANCE SCANS OF THE CERVICALSPINE IN ASYMPTOMATIC SUBJECTS - A PROSPECTIVE INVESTIGATION. J Bone Joint Surg-Am Vol. 1990;72A:8.1178-84.

28. Bohlman HH. ACUTE FRACTURES AND DISLOCATIONS OF THE CERVICAL-SPINE ANALYSIS OF 300 HOSPITALIZED-PATIENTS AND REVIEW OF THE LITERATURE. $J$ Bone Joint Surg-Am Vol. 1979;61:8.1119-42.

29. Stiell IG, Wells GA, Vandemheen KL, Clement CM, Lesiuk H, De Maio VJ, et al. The Canadian Cspine rule for radiography in alert and stable trauma patients. JAMA-J Am Med Assoc.

2001;286:15.1841-8.

30. Ranawat CS, Oleary P, Pellicci P, Tsairis P, Marchisello P, Dorr L. CERVICAL-SPINE FUSION IN RHEUMATOID-ARTHRITIS. J Bone Joint Surg-Am Vol. 1979;61:7.1003-10.

31. Resnick D, Niwayama G. RADIOGRAPHIC AND PATHOLOGIC FEATURES OF SPINAL INVOLVEMENT IN DIFFUSE IDIOPATHIC 
SKELETAL HYPEROSTOSIS (DISH). Radiology. 1976;119:3.559-68.

32. Bailey RW, Badgley CE. STABILIZATION OF THE CERVICAL SPINE BY ANTERIOR FUSION. J Bone Joint Surg-Am Vol. 1960;42:4.565-94. 33. Bovim G, Schrader H, Sand T. NECK PAIN IN THE GENERAL-POPULATION. Spine. 1994;19:12.1307-9.

34. Hirabayashi K, Watanabe K, Wakano K, Suzuki N, Satomi K, Ishii Y. EXPANSIVE OPEN-DOOR LAMINOPLASTY FOR CERVICAL SPINAL STENOTIC MYELOPATHY. Spine. 1983;8:7.693-9. 35. Payne EE, Spillane JD. THE CERVICAL SPINE - AN ANATOMICO-PATHOLOGICAL STUDY OF 70 SPECIMENS (USING A SPECIAL TECHNIQUE) WITH PARTICULAR REFERENCE TO THE PROBLEM OF CERVICAL SPONDYLOSIS. Brain. 1957;80:4.571-96.

36. Schneider RC, Cherry G, Pantek H. THE SYNDROME OF ACUTE CENTRAL CERVICAL SPINAL CORD INJURY - WITH SPECIAL REFERENCE TO THE MECHANISMS INVOLVED IN HYPEREXTENSION INJURIES OF CERVICAL SPINE. J Neurosurg. 1954;11:6.546-77. 37. Eck JC, Humphreys SC, Lim TH, Jeong ST, Kim JG, Hodges SD, et al. Biomechanical study on the effect of cervical spine fusion on adjacent-level intradiscal pressure and segmental motion. Spine. 2002;27:22.2431-4.

38. Barnsley L, Lord S, Bogduk N. WHIPLASH INJURY. Pain. 1994;58:3.283-307.

39. Allen BL, Ferguson RL, Lehmann TR, Obrien RP. A MECHANISTIC CLASSIFICATION OF CLOSED, INDIRECT FRACTURES AND DISLOCATIONS OF THE LOWER CERVICALSPINE. Spine. 1982;7:1.1-27.

40. Wright NM, Lauryssen C. Vertebral artery injury in C1-2 transarticular screw fixation: Results of a survey of the AANS/CNS section on disorders of the spine and peripheral nerves. J Neurosurg. 1998;88:4.634-40.

41. Pang D, Wilberger JE. SPINAL-CORD INJURY WITHOUT RADIOGRAPHIC ABNORMALITIES IN CHILDREN. J Neurosurg. 1982;57:1.114-29.

42. Schrader H, Obelieniene D, Bovim G, Surkiene D, Mickeviciene D, Miseviciene I, et al. Natural evo- lution of late whiplash syndrome outside the medicolegal context. Lancet. 1996;347:9010.1207-11. 43. Sen CN, Sekhar LN. AN EXTREME LATERAL APPROACH TO INTRADURAL LESIONS OF THE CERVICAL-SPINE AND FORAMEN MAGNUM. Neurosurgery. 1990;27:2.197-204. 44. Jones EL, Heller JG, Silcox DH, Hutton WC. Cervical pedicle screws versus lateral mass screws Anatomic feasibility and biomechanical comparison. Spine. 1997;22:9.977-82.

45. Abumi K, Shono Y, Ito M, Taneichi H, Kotani Y, Kaneda K. Complications of pedicle screw fixation in reconstructive surgery of the cervical spine. Spine. 2000;25:8.962-9.

46. Gore DR, Sepic SB, Gardner GM. ROENTGENOGRAPHIC FINDINGS OF THE CERVICAL-SPINE IN ASYMPTOMATIC PEOPLE. Spine. 1986;11:6.521-4.

47. Panjabi MM, Duranceau J, Goel V, Oxland T, Takata K. CERVICAL HUMAN VERTEBRAE QUANTITATIVE 3-DIMENSIONAL ANATOMY OF THE MIDDLE AND LOWER REGIONS.

Spine. 1991;16:8.861-9.

48. Radanov BP, Sturzenegger M, Distefano G. LONG-TERM OUTCOME AFTER WHIPLASH INJURY - A 2-YEAR FOLLOW-UP CONSIDERING FEATURES OF INJURY MECHANISM AND SOMATIC, RADIOLOGIC, AND PSYCHOSOCIAL FINDINGS. Medicine.

1995;74:5.281-97.

49. Grob D, Jeanneret B, Aebi M, Markwalder TM. ATLANTOAXIAL FUSION WITH TRANSARTICULAR SCREW FIXATION. J Bone Joint SurgBr Vol. 1991;73:6.972-6.

50. Hurwitz EL, Aker PD, Adams AH, Meeker WC, Shekelle PG. Manipulation and mobilization of the cervical spine - A systematic review of the literature. Spine. 1996;21:15.1746-59.

51. Kotani Y, Cunningham BW, Abumi K, McAfee PC. BIOMECHANICAL ANALYSIS OF CERVICAL STABILIZATION SYSTEMS - AN ASSESSMENT OF TRANSPEDICULAR SCREW FIXATION IN THE CERVICAL-SPINE. Spine. 1994;19:22.2529-39.

52. Jull G, Trott P, Potter H, Zito G, Niere K, Shirley D, et al. A randomized controlled trial of exercise and manipulative therapy for cervicogenic 
headache. Spine. 2002;27:17.1835-43.

53. Sambrook PN, MacGregor AJ, Spector TD. Genetic influences on cervical and lumbar disc degeneration - A magnetic resonance imaging study in twins. Arthritis Rheum. 1999;42:2.366-72.

54. Penning L. NORMAL MOVEMENTS OF CERVICAL-SPINE. Am J Roentgenol.

1978;130:2.317-26.

55. Ylinen J, Takala EP, Nykanen M, Hakkinen A, Malkia E, Pohjolainen T, et al. Active neck muscle training in the treatment of chronic neck pain in women - A randomized controlled trial. JAMA-J Am Med Assoc. 2003;289:19.2509-16.

56. Davis JW, Phreaner DL, Hoyt DB, Mackersie RC. THE ETIOLOGY OF MISSED CERVICALSPINE INJURIES. J Trauma-Injury Infect Crit Care. 1993;34:3.342-6.

57. Mummaneni PV, Burkus JK, Haid RW, Traynelis VC, Zdeblick TA. Clinical and radiographic analysis of cervical disc arthroplasty compared with allograft fusion: a randomized controlled clinical trial. J Neurosurg-Spine. 2007;6:3.198-209.

58. Fang HSY, Ong GB. DIRECT ANTERIOR APPROACH TO THE UPPER CERVICAL SPINE. $J$ Bone Joint Surg-Am Vol. 1962;44:8.1588-604. 59. Goffin J, Van Calenbergh F, van Loon J, Casey A, Kehr P, Liebig K, et al. Intermediate follow-up after treatment of degenerative disc disease with the Bryan Cervical Disc Prosthesis: Single-level and bilevel. Spine. 2003;28:24.2673-8. 60. Teresi LM, Lufkin RB, Reicher MA, Moffit BJ, Vinuela FV, Wilson GM, et al. ASYMPTOMATIC DEGENERATIVE DISK DISEASE AND SPONDYLOSIS OF THE CERVICAL-SPINE MR IMAGING. Radiology. 1987;164:1.83-8. 61. Abumi K, Itoh H, Taneichi H, Kaneda K. TRANSPEDICULAR SCREW FIXATION FOR TRAUMATIC LESIONS OF THE MIDDLE AND LOWER CERVICAL-SPINE - DESCRIPTION OF THE TECHNIQUES AND PRELIMINARYREPORT. J Spinal Disord. 1994;7:1.19-28. 62. Conlon PW, Isdale IC, Rose BS. RHEUMATOID ARTHRITIS OF CERVICAL SPINE - AN ANALYSIS OF 333 CASES. Ann Rheum Dis. 1966;25:2.120-6.

63. Rogers WA. FRACTURES AND DISLOCATIONS OF THE CERVICAL SPINE - AN END-
RESULT STUDY. J Bone Joint Surg-Am Vol. 1957;39:2.341-76.

64. Emery SE, Bohlman HH, Bolesta MJ, Jones

PK. Anterior cervical decompression and arthrodesis for the treatment of cervical spondylotic myelopathy - Two to seventeen-year follow-up. J Bone Joint Surg-Am Vol. 1998;80A:7.941-51.

65. Vaccaro AR, Falatyn SP, Scuderi GJ, Eismont FJ, McGuire RA, Singh K, et al. Early failure of long segment anterior cervical plate fixation. J Spinal Disord. 1998;11:5.410-5.

66. Youdas JW, Carey JR, Garrett TR. RELIABILITY OF MEASUREMENTS OF CERVICALSPINE RANGE OF MOTION - COMPARISON OF 3 METHODS. Phys Ther. 1991;71:2.98-104.

67. Southwick WO, Robinson RA. SURGICAL APPROACHES TO THE VERTEBRAL BODIES IN THE CERVICAL AND LUMBAR REGIONS. $J$ Bone Joint Surg-Am Vol. 1957;39:3.631-44.

68. Buskila D, Neumann L, Vaisberg G, Alkalay D, Wolfe F. Increased rates of fibromyalgia following cervical spine injury - A controlled study of 161 cases of traumatic injury. Arthritis Rheum.

1997;40:3.446-52.

69. Goffin J, Geusens E, Vantomme N, Quintens E, Waerzeggers Y, Depreitere B, et al. Long-term follow-up after interbody fusion of the cervical spine. J Spinal Disord Tech. 2004;17:2.79-85.

70. Stiell IG, Clement CM, McKnight RD, Brison $\mathrm{R}$, Schull MJ, Rowe BH, et al. The canadian C-spine rule versus the NEXUS low-risk criteria in patients with trauma. NEngl J Med. 2003;349:26.2510-8.

71. Flanders AE, Schaefer DM, Doan HT, Mishkin MM, Gonzalez CF, Northrup BE. ACUTE CERVICAL-SPINE TRAUMA - CORRELATION OF MR IMAGING FINDINGS WITH DEGREE OF NEUROLOGIC DEFICIT. Radiology. 1990;177:1.25-33.

72. Sawin PD, Traynelis VC, Menezes AH. A comparative analysis of fusion rates and donor-site morbidity for autogeneic rib and iliac crest bone grafts in posterior cervical fusions. $J$ Neurosurg.

1998;88:2.255-65.

73. Clark CR, White AA. FRACTURES OF THE DENS - A MULTICENTER STUDY. J Bone Joint Surg-Am Vol. 1985;67A:9.1340-8.

74. Cattell HS, Filtzer DL. PSEUDOSUBLUXA- 
TION AND OTHER NORMAL VARIATIONS IN CERVICAL SPINE IN CHILDREN . A STUDY OF 160 CHILDREN. J Bone Joint Surg-Am Vol. 1965;A 47:7.1295-309.

75. Fountas KN, Kapsalaki EZ, Nikolakakos LG, Smisson HF, Johnston KW, Grigorian AA, et al. Anterior cervical Discectomy and fusion associated complications. Spine. 2007;32:21.2310-7.

76. Kaiser MG, Haid RW, Subach BR, Barnes B, Rodts GE. Anterior cervical plating enhances arthrodesis after discectomy and fusion with cortical allograft. Neurosurgery. 2002;50:2.229-36.

77. Levine AM, Edwards CC. THE MANAGEMENT OF TRAUMATIC SPONDYLOLISTHESIS OF THE AXIS. J Bone Joint Surg-Am Vol. 1985;67A:2.217-25.

78. Wada E, Suzuki S, Kanazawa A, Matsuoka T, Miyamoto S, Yonenobu K. Subtotal corpectomy versus laminoplasty for multilevel cervical spondylotic myelopathy - A long-term follow-up study over 10 years. Spine. 2001;26:13.1443-7.

79. Smucker JD, Rhee JM, Singh K, Yoon ST, Heller JG. Increased swelling complications associated with off-label usage of rhBMP-2 in the anterior cervical spine. Spine. 2006;31:24.2813-9.

80. Boden SD, Dodge LD, Bohlman HH, Rechtine GR. RHEUMATOID-ARTHRITIS OF THE CERVICAL-SPINE - A LONG-TERM ANALYSIS WITH PREDICTORS OF PARALYSIS AND RECOVERY. J Bone Joint Surg-Am Vol.

1993;75A:9.1282-97.

81. Murrey D, Janssen M, Delamarter R, Goldstein J, Zigler J, Tay B, et al. Results of the prospective, randomized, controlled multicenter Food and Drug Administration investigational, device exemption study of the ProDisc-C total disc replacement versus anterior discectomy and fusion for the treatment of 1-level symptomatic cervical disc disease. Spine Journal. 2009;9:4.275-86.

82. Hosono N, Yonenobu K, Ono K. Neck and shoulder pain after laminoplasty - A noticeable complication. Spine. 1996;21:17.1969-73.

83. Bazaz R, Lee MJ, Yoo JU. Incidence of dysphagia after anterior cervical spine surgery - A prospective study. Spine. 2002;27:22.2453-8.

84. Vasavada AN, Li SP, Delp SL. Influence of muscle morphometry and moment arms on the moment- generating capacity of human neck muscles. Spine. 1998;23:4.412-22.

85. Dickman CA, Sonntag VKH, Papadopoulos SM, Hadley MN. THE INTERSPINAL METHOD OF POSTERIOR ATLANTOAXIAL ARTHRODESIS. J Neurosurg. 1991;74:2.190-8.

86. Panjabi MM, Crisco JJ, Vasavada A, Oda T, Cholewicki J, Nibu K, et al. Mechanical properties of the human cervical spine as shown by threedimensional load-displacement curves. Spine. 2001;26:24.2692-700.

87. Aker PD, Gross AR, Goldsmith CH, Peloso P. Conservative management of mechanical neck pain: Systematic overview and meta-analysis. $\mathrm{Br} \mathrm{Med} \mathrm{J.}$ 1996;313:7068.1291-6.

88. Itoh T, Tsuji H. TECHNICAL IMPROVEMENTS AND RESULTS OF LAMINOPLASTY FOR COMPRESSIVE MYELOPATHY IN THE CERVICAL-SPINE. Spine. 1985;10:8.729-36.

89. Pellicci PM, Ranawat CS, Tsairis P, Bryan WJ. A PROSPECTIVE-STUDY OF THE PROGRESSION OF RHEUMATOID-ARTHRITIS OF THE CERVICAL-SPINE. J Bone Joint Surg-Am Vol. 1981;63:3.342-50.

90. Abumi K, Takada T, Shono Y, Kaneda K, Fujiya M. Posterior occipitocervical reconstruction using cervical pedicle screws and plate-rod systems. Spine. 1999;24:14.1425-34.

91. Heller JG, Sasso RC, Papadopoulos SM, Anderson PA, Fessler RG, Hacker RJ, et al. Comparison of BRYAN Cervical Disc Arthroplasty With Anterior Cervical Decompression and Fusion Clinical and Radiographic Results of a Randomized, Controlled, Clinical Trial. Spine. 2009;34:2.101-7.

92. Abumi K, Kaneda K. Pedicle screw fixation for nontraumatic lesions of the cervical spine. Spine. 1997;22:16.1853-63.

93. Melcher RP, Puttlitz CM, Kleinstueck FS, Lotz JC, Harms J, Bradford DS. Biomechanical testing of posterior atlantoaxial fixation techniques. Spine. 2002;27:22.2435-40.

94. Katsuura A, Hukuda S, Saruhashi Y, Mori K. Kyphotic malalignment after anterior cervical fusion is one of the factors promoting the degenerative process in adjacent intervertebral levels. Eur Spine J. 2001;10:4.320-4.

95. Perry J, Nickel VL. TOTAL CERVICAL- 
SPINE FUSION FOR NECK PARALYSIS. J Bone Joint Surg-Am Vol. 1959;41:1.37-60.

96. Matsumoto M, Fujimura Y, Suzuki N, Nishi Y, Nakamura M, Yabe Y, et al. MRI of cervical intervertebral discs in asymptomatic subjects. J Bone Joint Surg-Br Vol. 1998;80B:1.19-24.

97. Johnson RM, Hart DL, Simmons EF, Ramsby GR, Southwick WO. CERVICAL ORTHOSES STUDY COMPARING THEIR EFFECTIVENESS IN RESTRICTING CERVICAL MOTION IN NORMAL SUBJECTS. J Bone Joint Surg-Am Vol. 1977;59:3.332-9.

98. Richter M, Schmidt R, Claes L, Puhl W, Wilke HJ. Posterior atlantoaxial fixation - Biomechanical in vitro comparison of six different techniques. Spine. 2002;27:16.1724-32.

99. Bogduk N, Mercer S. Biomechanics of the cervical spine. I: Normal kinematics. Clin Biomech. 2000;15:9.633-48.

100. Gore DR, Sepic SB, Gardner GM, Murray MP. NECK PAIN - A LONG-TERM FOLLOW-UP OF 205 PATIENTS. Spine. 1987;12:1.1-5. 101. Torg JS, Pavlov H, Genuario SE, Sennett B, Wisneski RJ, Robie BH, et al. NEURAPRAXIA OF THE CERVICAL SPINAL-CORD WITH TRANSIENT QUADRIPLEGIA. J Bone Joint Surg-Am Vol. 1986;68A:9.1354-70.

102. Sakaura H, Hosono N, Mukai $Y$, Ishii T, Yoshikawa H. C5 palsy after decompression surgery for cervical myelopathy - Review of the literature. Spine. 2003;28:21.2447-51.

103. Wang JC, McDonough PW, Endow KK, Delamarter RB. Increased fusion rates with cervical plating for two-level anterior cervical discectomy and fusion. Spine. 2000;25:1.41-5.

104. Matsunaga S, Kabayama S, Yamamoto T, Yone K, Sakou T, Nakanishi K. Strain on intervertebral discs after anterior cervical decompression and fusion. Spine. 1999;24:7.670-5.

105. Wainner RS, Fritz JM, Irrgang JJ, Boninger ML, Delitto A, Allison S. Reliability and diagnostic accuracy of the clinical examination and patient selfreport measures for cervical radiculopathy. Spine. 2003;28:1.52-62.

106. Coe JD, Warden KE, Sutterlin CE, McAfee PC. BIOMECHANICAL EVALUATION OF CERVICAL SPINAL STABILIZATION METHODS IN
A HUMAN CADAVERIC MODEL. Spine. 1989;14:10.1122-31.

107. Tan MS, Wang HM, Wang YT, Zhang GB, Yi $\mathrm{P}, \mathrm{Li} \mathrm{ZR}$, et al. Morphometric evaluation of screw fixation in atlas via posterior arch and lateral mass. Spine. 2003;28:9.888-95.

108. Resnick DK, Lapsiwala S, Trost GR. Anatomic suitability of the C1-C2 complex for pedicle screw fixation. Spine. 2002;27:14.1494-8.

109. Resnick DK, Benzel EC. C1-C2 pedicle screw fixation with rigid cantilever beam construct: Case report and technical note. Neurosurgery.

2002;50:2.426-8.

110. Hacker RJ, Cauthen JC, Gilbert TJ, Griffith SL. A prospective randomized multicenter clinical evaluation of an anterior cervical fusion cage. Spine. 2000;25:20.2646-54.

111. Nayer Sk, Dein Ej, Spiker AM, Bernard JA and Zikira BA. The top 100 cited articles in Clinical Orthopedic sports medicine. Am j Orthop. 2015

Aug;44(8): E252-61

112. Namdari S, Baldwin K, Kovatch K, Huffman GR and Glaser D. Fifty most cited articles in orthopedic shoulder surgery. J Shoulder Elbow Srg 2012; 21: 1796-1802

113. Murray MR, Wang T, Schroeder GD and Hsu WK. The 100 most cited spine articles. Eur Spine J 2012; 21(10):2059-2069

114. Ruegsegger N, Ahmad SS, Benneker LM et al. The 100 most influential publications in cervical spine research. Spine 2016; 41(6): 538-548.

\section{Disclosures \& COI}

The authors declare no relevant financial disclosures.

\section{Corresponding Author}

Yu Chao Lee, The Spinal Unit, Department of Orthopaedics and Trauma, Royal Adelaide Hospital, Adelaide, SA, Australia. ychao83@hotmail.com.

Published 28 June 2017.

This manuscript is generously published free of charge by ISASS, the International Society for the Advancement of Spine Surgery. Copyright ๑ 2017 ISASS. To see more or order reprints or permissions, see http://ijssurgery.com. 